imperfections - will continue to be widely used, though it will be interesting to see whether moves towards discretionary rather than profiling analysers and the introduction of clinical budgeting will affect the patterns of requests made by clinicians.

Reader in Clinical Biochemistry,

M F LAKER

University of Newcastle upon Tyne Medical School,

Newcastle upon Tyne NE2 4HH

1 Price CP, Alberti KGMM. Biochemical assessment of liver function. In: Wright R, MillwardSadler GH, Alberti KGMM, Karran S, eds. Liver and biliary diseases. 2nd ed. London: Baillière Tindall, 1985:455-94.

2 Galen RS, Gambino SR. Beyond normality: the predictive value and efficiency of medical diagnoses. New York: John Wiley, 1.975

3 Galambos JT, Wills CE. Relationship between 505 paired liver tests and biopsies in 242 obese patients. Gastroenterology 1978;74:1191-5.

4 Van Ness MM, Diehl AM. Is liver biopsy useful in the evaluation of patients with chronically elevated liver enzymes? Ann Intern Med 1989;111:473-8.

5 Maharaj B, Maharaj RJ, Leary WP, et al. Sampling variability and its influence on the diagnostic yield of percutaneous needle biopsy of the liver. Lancet 1986;i:523-5.

6 Fisher RL, Anderson RW, Boyer JL, et al. A prospective morphologic evaluation of hepatic toxicity of chenodeoxycholic acid (CDCA) in patients with cholelithiasis: The national cooperative gallstone study. Hepatology 1982;2:187-201.

7 Hofmann AF. The aminopyrine demethylation breath test and the serum bile acid level: nominated but not yet elected to join the common liver tests. Hepatology 1982;2:512-7.

8 Skrede S, Solberg HE, Blomhoff JP, Gjone E. Bile acids measured in serum during fasting as a test for liver disease. Clin Chem 1978;24:1095-9.

9 Monroe PS, Baker AL, Schneider JF, Krager PS, Klein PD, Schoeller D. The aminopyrine breath test and serum bile acids reflect histologic severity in chronic hepatitis. Hepatology 1982;2: $317-22$.

10 Renner E, Wietholtz H, Huguenin P, Arnaud MJ, Presig R. Caffeine: a model compound for measuring liver function. Hepatology 1984;4:38-46.

11 Johnson PJ. Role of the standard "liver function tests" in current clinical practice. Ann Clin Biochem 1989;26:463-71.

12 Beckett GJ, Hayes JD. Plasma glutathione S-transferase measurements in liver disease in man. fournal of Clinical Biochemistry and Nutrition 1987;2:1-24

13 Hayes PC, Hussey AJ, Keating J, et al. Glutathione S-transferase in autoimmune chronic active hepatitis: a more sensitive index of hepatocellular damage than aspartate aminotransferase. Clin Chim Acta 1988;172:211-6.

14 Fevery J, Blanckaert $\mathrm{N}$. What can we learn from analysis of serum bilirubin? $\mathcal{f}$ Hepatology 1986;2:113-21

15 Storey EL, Anderson GJ, Mack U, Powell LW, Halliday JW. Desialylated transferrin as a serological marker of chronic excessive alcohol ingestion. Lancet 1987;i:1292-4.

16 Lumeng L. New diagnostic markers of alcohol abuse. Hepatology 1986;6:742-5.

16 Lumeng L. New diagnostic markers of alcohol abuse. Hepatology 1986;6:742-5. Babbs C, Smith A, Hunt LP, Rowan BP, Haboubi NY, Warnes TW. Type III collagen peptide:
marker of disease activity and prognosis in primary biliary cirrhosis. Lancet 1988;i:1021-4.

18 Yeaman SJ, Fussey SPM, Danner DJ, James OFW, Bassendine MF. Primary biliary cirrhosis identification of a major M2 mitochondrial autoantigen. Lancet 1988; i: 1067-70.

\section{Is antenatal selection for spina bifida possible?}

\section{Not until we have a reliable anatomical indicator in the midtrimester}

About 20 years ago the management of newborn babies with open spina bifida changed from routine operative treatment of all infants to a policy of selective surgery for only those whom it was predicted would benefit. Selection was based on specific adverse criteria, formulated by Lorber, known to result in death or severe and irremediable handicap, even when surgery was performed. ${ }^{1}$ Although not universally accepted, such a selection policy has been widely practised. Concurrently, however, the number of babies born with spina bifida has diminished, largely because of prenatal diagnosis followed by termination of pregnancy. Hunt has recently speculated on the possibility of a prenatal selection policy, similar to the policy practised at birth. ${ }^{2}$ Is it possible to distinguish in the midtrimester between those babies likely to have minimal or no handicap and those who will become severely disabled?

The benefit of a selection policy emerges from Hunt's review of the outcomes, at 16-20 years, for 117 consecutive children born with open spina bifida. ${ }^{2}$ Their lesions would have been associated in utero with a raised $\alpha$ fetoprotein concentration. Had they been conceived only a few years later their condition would probably have been diagnosed prenatally, termination of pregnancy offered, and, for those who did not undergo termination, selective surgery practised at birth. As it was, all of the infants were treated at birth with closure of their back lesions within 48 hours. As expected, the outcome has been grim for most: 25 did not survive their first year, and 48 were dead before their 16th birthday. Of the 69 who survived to the age of 16,60 had had a shunt inserted for hydrocephalus and two became blind because of shunt dysfunction; 22 were mentally retarded; 12 needed continued anticonvulsant treatment; 52 were incontinent; 35 were dependent on wheelchairs; and 33 needed lifelong care. Nevertheless, eight young people $-12 \%$ of the survivors and $7 \%$ of the total cohort - had little or no disability. One young man who had a shunt inserted at the age of 7 months has an intelligence quotient of 138 and has represented his county at tennis.

If the $7 \%$ of infants who will live reasonable lives are to be identified in utero then what is needed is the presence in the midtrimester of reliable predictive indicators of the long term outcome that can be visualised by ultrasonography. Prenatal diagnosis of spina bifida was first achieved by $\alpha$ fetoprotein assay, which was an indiscriminate tool. Now, however, diagnosis is by ultrasonography, performed universally in antenatal care in Britain, and capable of identifying each individual fetal vertebra and locating the precise site of a spinal lesion-although what is actually observed is influenced by such factors as maternal obesity and fetal mobility and position. Despite the potential for precision, however, diagnosis based on the findings on ultrasonography tends to be used indiscriminately, termination being offered whenever a spinal lesion is seen.

Some of Lorber's adverse criteria-lesions at the thoracolumbar vertebral levels and kyphosis of the spine-could be visualised by ultrasonography in the midtrimester, so that the most severely affected fetuses could be identified. Hydrocephalus too is usually easily diagnosable; indeed, it often alerts the sonographer to the presence of spina bifida. After birth $90 \%$ of infants with open spina bifida need shunts inserted, but hydrocephalus is not a reliable prognostic indicator, for some infants will have unpredictable complications and become blind, epileptic, or mentally retarded, while others will have no secondary consequences.

Scanning may also identify those fetuses with "low" spinal lesions, say at L3 and below, but such lesions do not necessarily indicate a mild course. In one study $35(24 \%)$ of 146 such patients died; 64 of the survivors with low lesions had long term follow up; $19 \%$ were mentally retarded, $53 \%$ went to special schools, $93 \%$ had a urinary appliance, and, although all were mobile, $56 \%$ needed splints. ${ }^{3}$ In fact the extent of handicap that a person with spina bifida experiences is determined not by the site of the lesion but almost entirely by the neurological deficit.

Hunt et al found that at birth the best predictor of neurological deficit was the sensory level. ${ }^{4}$ This is determined by response to a pinprick and is the first demonstration of normal sensation above the area of anaesthesia. It does not correspond to either the radiological level or the cutaneous extent of the lesions. The eight patients in Hunt's recent study who ended up with minimal handicap had bony lesions in the thoracic spine (one patient), lumbar spine (two patients), and lumbosacral spine (five patients). ${ }^{1}$ Conversely, three others with lumbosacral bony lesions were among the most gravely handicapped. But the first group had almost full sensation at birth, while in the second the sensory level was at T10 or L1. The sensory level correlates with eventual function in terms of 
mobility, intelligence, continence, and renal damage. Others too have found that determining the neurological function, by charting the activity of specific muscles, is useful postnatally in predicting mortality and quality of life among survivors. ${ }^{3}$ But, as with the sensory level, muscle activity cannot be determined in utero.

It is hard to think what factor might be used. Flexion and extension of knees and hips have been seen to be normal on ultrasonography at around 17 weeks' gestation in fetuses with spina bifida, ${ }^{5}$ so movement is not informative. Neither is the diagnosis of renal malformations as these occur in only $15 \%$ of fetuses with spina bifida. ${ }^{6}$ Until a reliable anatomical prognostic indicator is found the prospects for selective termination of fetuses with open spina bifida in utero do not seem good.

Reader in Developmental Genetics,

MARY J SELLER

Division of Medical and Molecular Genetics,

Guy's Hospital,

London SE1 9RT

1 Lorber J. Results of treatment of myelomeningocele. An analysis of 524 unselected cases with specia reference to possible selection for treatment. Dev Med Child Neurol 1971;13:279-303.

2 Hunt GM. Open spina bifida; outcome for a complete cohort treated unselectively and followed into adulthood. Dev Med Child Neurol 1990;32:108-18.

Smith GK, Smith ED. Selection for treatment in spina bifida cystica. Br Med f 1973;iv: 189-97.

4 Hunt G, Lewin W, Gleave J, Gairdner D. Predictive factors in open myelomeningocele with special reference to sensory level. Br Med f 1973;iv: 197-20

5 Korenromp MJ, Van Gool JD, Bruinese HW, Kreik R. Early fetal leg movements in myelomeningocoele. Lancet $1986 ;$; $917-8$.

6 Hunt GM, Whitaker RH. The pattern of congenital renal anomalies associated with neural tube defects. Dev Med Child Neurol 1987;29:91-5.

\section{The ghost of Edwin Chadwick}

\section{We need more giants like him-ready to take on governments}

Not so long ago a healthierr, safer Britain seemed assured. Epidemics had dwindled, and hygiene was improving. Public health's mission apparently accomplished, the medical officer of health was painlessly put to sleep in 1974. A new beast, community medicine, moved into his shoes programmed for "management."

Today that optimism seems misplaced. Legionnaires' disease, salmonella, AIDS, drug misuse, homelessness, pollution, and environmental blight are all rampantsymptoms of the deprivation and despair created by divisive socioeconomic policies. Once more the inner city is crumbling into a health and welfare nightmare, redolent of Dickensian horrors. What has medicine to say? The Victorian Public Health Legacy: a Challenge for the Future speaks out.'

This pamphlet, issued by the Public Health Alliance and the Institution of Environmental Health Officers to mark the centenary of Edwin Chadwick's death, reminds us that it was to tackle just these problems that public health was created. Faced with the sickness and crises spawned by industrialisation, Edwin Chadwick, Sir John Simon, Florence Nightingale, and others perceived that ill health could not be remedied in isolation from the wider problems of destitution, slums, smoke, water supply, and sewage.

These were matters not for personal but for public action, and they demanded political solutions. In 1848 Chadwick badgered parliament into setting up the General Board of Health, distant forerunner of the Ministry of Health. Following a more "softly softly" approach, Sir John Simon, chief medical officer to the Privy Council, planted public health in the provinces. Their achievements were consolidated in the great Public Health Act 1875. By the close of the century battalions of medical officers of health armed with statutory powers were overcoming disease and filth.

Ironically, success proved their undoing. Retrenchment set in, public health lost its way, and newer radical groups championed the people's health. With the advent of the NHS the public health profession was reduced to a Cinderella service-hence its euthanasia in the NHS reorganisation of 1974.

This run down must be reversed. Endangered by a deteriorating environment, we must learn the lessons of the past to confront the "challenge of the future." It is time to tune our ears to the real Victorian values and make our priority prevention. Not least, as the costs of curative medicine spiral, preventive medicine makes economic sense. "In all sorts of preventable illness," Simon himself emphasised, "it is the public that, too late for the man's health or independence, pays the arrears of wages which should have hindered this suffering and sorrow."

Above all, argues the pamphlet's author, medical historian Charles Webster, prevention should be our social goal. The past decade has seen the inequalities of health pinpointed by the Black report worsen. If Britain is to provide "health for all"-and, as signatories to the World Health Organisation Charter on Environment and Health, that is our obligationit is time to tackle not just the symptoms but the causes of sickness in our society, by grasping its connections with wages, working conditions, housing standards, and nutrition.

This will need leadership. Whitehall grooms grey technocrats trapped in bureaucratic machines; Where, Webster asks, are the health warriors of our time? Giants like Chadwick and Simon spoke out for public health. They took on the governments of their day. We should take our inspiration from them.

But not blindly. For Chadwick himself was a Jekyll and Hyde figure. He was a crusading reformer, but he was also the infamous author of the Victorian poor law, with its workhouse system; an arrogant centraliser; and a detester of doctors. This last Chadwick would doubtless be welcomed with open arms by many politicians. It is the other Chadwick, the public health champion, we should honour today.

Assistant Professor,

DOROTHY PORTER

Department of the History of Science,

Harvard University,

Cambridge,

Massachusetts 02138 ,

United States

Senior Lecturer in the Social History of Medicine,

ROY PORTER

Wellcome Institute for the History of Medicine,

London NW1 2BN

1 Webster C. The Victorian public health legacy: a challenge for the future. London: Public Health Alliance and Institution of Environmental Health Officers, 1990. 